\title{
Uses of Social Media among Selected Labour Unions in Abuja during Nigeria's (January 2012) “Oil Subsidy” Removal Protests
}

\author{
Michael Aondo-verr Kombol ${ }^{1}$ \\ ${ }^{1}$ Dept of Mass Communication, Benue State University, Makurdi, Nigeria. \\ Correspondence: M. A. Kombol, P. O. Box 2998 Makurdi, Benue State 970001, Nigeria.
}

Received: May 1, 2014 Accepted: May 8, 2014 Available online: May 28, 2014

doi:10.11114/smc.v2i1.401 URL: http://dx.doi.org/10.11114/smc.v2i1.401

\begin{abstract}
The removal of oil subsidy in Nigeria (January 2012) sparked protests across the country and a nationwide strike action organised by the Nigerian Labour Congress (NLC). This study examines the role of social media during these protests. This study ascertains why people in Nigeria used social media during the protests instead of other pre-existing mediaradio, television, newspapers, magazines, etc. Furthermore, it identifies the purposes for which social media was used (and by whom) during the protest whether intended or otherwise. For instance, in what ways can social media influence public opinion/mobilise people and groups to protest? Using a survey the study finds that: social media was used during these protests because restrictions in other media stifle expressions of individual opinion in the public sphere. A significant percentage of the opinion expressed via social media during these protests was of frustration due to mismanagement and corruption by the Nigerian government. Pictures, factual/statistical evidence and intelligent analysis of issues were a persuasive force on social media which shaped public opinion and mobilised people to go out on the streets.
\end{abstract}

Keywords: social media, subsidy, oil, protest, labour union.

\section{Introduction}

Removal of fuel subsidy is not new to Nigerians. Over the years, successive regimes in Nigeria have revisited this policy for a number of reasons. At each of these times, people in Nigeria have protested due to the effect of such policies. While the government may have its own reasons for removing subsidy, the masses are all too familiar with the ill-effects which the implementation of this policy has on the livelihood of ordinary people. There is often a chain effect in the economy. An increase in the pump price of fuel and other petroleum products simply translates to higher costs further down the line- transportation, food, health care, education, security, other services, etc. This reason often leads the masses to protest in order to let government know the effect of the policy.

In comparison to removal of fuel subsidy, social media are relatively new phenomena in Nigeria. In the early days of internet use in developing countries such as Nigeria, access was a big issue. Many people were "technology illiterate" and could not afford access to the internet because it was very expensive. With time, improvements in technology have brought about internet access on mobile phones and with competition from various actors in the sector, prices of internet services have continued to become more affordable. Mobile phone companies struggle to get an increasing market share, thus come up with promotions and sales strategies. Over time, internet access on mobile phones has become cheaper due to competition from mobile phone companies. The result of this is a proliferation of internet access on mobile phones. Some of these people who have internet access on their mobile phones use social media. Social media have become popular for a number of reasons. In the first place, social media allows instant publication of information in various formats on the internet- voice, text, pictures, videos, etc. This is not possible with traditional media such as radio, television, newspapers and magazines. Furthermore, social media guarantee freedom of expression as well as anonymity. The removal of fuel subsidy raised grievances in the minds of the Nigerian populace but they cannot express themselves effectively via traditional media due to its restrictive nature. Furthermore, traditional media does not protect the identity of the source except for compelling reasons. On the other hand, social media offer some measure of confidentiality to its users. According to the International Telecommunications Union (2013), 39.6\% of all Internet Traffic from Africa is from Nigeria, thus, Nigeria has the largest number of Internet users in Africa. Boyd and Elison (2007) write that the popularity of social network sites has increased in Africa with improvements in technology 
especially the ability to browse the internet on mobile phones. It is pertinent to note that $90 \%$ of people on the internet are visiting social network sites. Deloitte (2012) finds that Facebook is the most visited social media on the African continent with 44.9 million people and $80 \%$ of Facebook logins which occur in Nigeria and South Africa are done via mobile devices. Social media is often the reason why many people in Africa browse the internet and they often do this via mobile devices.

This study examines the relevance of social media during the fuel subsidy removal protests that were held in January 2012. It is necessary to find out how social media was used during these protests because social media have unique features which are absent in traditional media. These unique features may have an effect on social issues and protest mobilisation. Castells (1996) writes that the Internet (and indeed social media) is a malleable technology which can be modified to suit specific uses leading to a number of outcomes. Hence labour unions may use social media to mobilise citizens for protest. This is often not feasible with traditional media. According to Gerlach (2001) digital technologies support activism because they are socially distributed with unique qualities: flat, flexible, resilient, non-hierarchical, etc. These features raise social media above traditional media and can make it potent with far reaching outcomes. Bennett (2003) adds that these features of new media offer activists independence from mass media (traditional media). With sufficient use of social media, there is no need for mass media due to a number of reasons, top of which is state control. Deloitte (2012) points to the potential of social media to change the face of politics in Africa especially by facilitating the organisation of political action among citizens who share particular interests. Chatora (2012) highlights the mediating role which social media have played in a number of protests in Africa and elsewhere in the world, namely: violent protests in the UK from July- August 2011; popular protests in Tunisia which forced President Zine el-Abidine Ben Ali out of office on 14 $4^{\text {th }}$ January 2011 and; protests in Egypt which precipitated the forced resignation of President Hosni Mubarack on $11^{\text {th }}$ Febrauary 2011. In this light, how was social media used to mobilise people in Nigeria during the fuel subsidy removal protests? It is pertinent also to find out why social media was used instead of traditional media and what kinds of comments/messages were placed on social media during the period.

\section{Definition of Terms}

\subsection{Social Media}

Social media are new phenomena in the evolution of Information and Communication Technologies. The workings of social media make it preferable to traditional media like radio, television, newspapers, etc. Social media have a number of advantages over traditional media. Chebib and Sohail (2011, p.140) write that, social media is used for communication by a large number of people in society and consists of: interactive websites; tagging websites; social news websites; social networking websites; photo and video sharing websites, etc. On the whole, any website that supports interactivity on the site and with other users is a social media website. Social media enable users perform a number of tasks. One of the many tasks which users perform on social media include: interactivity, commenting on profiles, networking, editing, etc. These tasks have improved the popularity of social media. Social media bring like minded people together at very low cost. The very act of bringing people together electronically enhances their capacities. They do not necessarily have to be brought together physically. Electronic meeting occasioned by social media saves time and cost. Papic and Noonan (2011, p.1) add that, social media enable like minded people organize themselves. Rather than attend meetings, workshops and rallies in person, people can anonymously pursue their interests on social media by joining a Facebook group or follow a Twitter feed at home. Thus revolutions and protests can be "made at home."

\subsection{Labour Union}

A labour union is an organised group of workers which represents the interests of these workers with regard to issues which affect them such as wages, taxes, entitlements, working conditions, retirement age, etc. Very often labour unions are invited to negotiate with employers and sometimes, government on behalf of the workers whom they represent. Labour unions strive to improve working conditions as they pursue the interests of workers. According to Farber (2001) labour unions are constituted by workers with the sole aim of collectively bargaining with the employer on issues pertaining to terms of employment and work conditions. Instead of discussing issues on an individual basis, labour unions take a collective approach and often may apply pressure where necessary (especially using work stoppages and strikes). During the January 2012 removal of subsidy on petroleum products in Nigeria, the Nigerian Labour Congress (NLC) which is the umbrella body for labour unions in Nigeria organised a nationwide strike action in order to revert the decision made by the government.

\section{Research Questions}

i. What purposes were social media used for during the fuel subsidy removal protests in Nigeria (January 2012)?

ii. Why were social media used during the fuel subsidy removal protests in Nigeria (January 2012)? 
iii. What kind of messages were posted on social media in reaction to various turn of events during the fuel subsidy removal protests in Nigeria (January 2012)?

\section{Theoretical Framework}

A study on the uses of social media in protest mobilisation is indeed an interesting one which involves a number of variables. Based on this fact, this study is explained by a number of theories: the social movement theory, the resource mobilisation theory and technological determinism.

Removal of subsidy and the consequent increase in the price of petrol can be perceived as an example of forcible repression. With the increase in the pump price of petrol, Nigerians suffer hardship because there is corresponding rise in the price of food, transport, health care, amenities, etc. Matters are made worse when government acts independent of public opinion thus members of the public feel uncared for. According to the social movement theory, Heberle (1995, p.58) writes that, forcible repression is an inappropriate course of action because social movenments occur when large sections of society feel that they are not properly treated in the existing social order. Due to this relegation, these people that start social movements hold the idea that they are in society but they are not truly recognised and treated as part of the society. Once forcible repression occurs, people look for means to organise themselves in groups and may express discontent especially via protest. Chatora (2012) argues that social media have the potential to facilitate political engagement by citizens and bring about political change in Africa. As a catalyst, social media may facilitate the evolution and success of social movements because it enables networks between aggrieved sections of society.

The removal of fuel subsidy is often perceived as forcible repression because there is no plausible reason for it. Nigerian leaders in the past who embarked on it are often perceived as serving personal interests instead of the interests of the Nigerian masses. This is because proceeds from past subsidy removal have not been appropriately channelled for development purposes. Removal of fuel subsidy implies an immediate increase in the pump price of petrol and other petroleum products such as kerosene, gasoline as well as cooking gas. Thus, the aftermath of such forcible repression is to revolt against the status quo. People will often protest when government does not act in their interest. In Nigeria, the protests against the removal of fuel subsidy led to the Occupy Nigeria Movement. This movement is similar to the Occupy Wall Street movement where the 99\% challenge the 1\% who dominates finance and business. Apart from Occupy Nigeria, there were a number of unions, civil society organisations, and others that organised the January 2012 protests against removal of fuel subsidy. The Occupy Nigeria Movement often used social media as alternative media of popular expression, because they could not use mass media in the same way for the purpose they intended to achieve. Fuchs (2010) explores the concept of alternative media as an avenue of criticism. Criticism of the Nigerian government especially on radio and television may not be tolerated because much of mass media in the country is state owned. In such situations where people are unable to find expression and representation in mass media, they actively seek other media that will accommodate their views and support their purpose. Rauch (2007) insists that alternative media goes beyond alternative: content; channels; sources and; values.The alternative approach to media is purpose driven. In the case of anti-government protest it is often the need to be heard, register discontent and effect change. Downing (2001) highlights the fact that alternative media are embedded in society. With the proliferation of mobile phones and mobile internet in Nigeria, social media have become rooted in Nigerian society. From this standpoint it can be used to: start discussion on social issues; stimulate political discourse and even mobilise people to protest.

Grievances such as those that led to the protest against fuel subsidy removal do not always lead to the creation of a social movement. According to Mayer (1995, p.173) the resource mobilization theory holds that grievances are "ubiquitous and constant," thus they do not always lead to the formation of a social movement. Indeed grievances are constantly occurring in society. In Nigeria alone, the public is faced with on issue after the other. It is not every time that an issue crops up that it will cause the evolution of a movement. The issue of removal of subsidy on petroleum products has been a recurring problem in Nigeria. Successive governments have removed subsidy at various times in the past. At each of these times, the Nigerian masses have protested against it. In some cases the prices were reverted.

Technology is every changing. As time passes by, new forms of technology evolve. However, it is not possible for technology on its own to bring about change. It is all about the way in which the technology is used to bring about change. This is the essence of the concept of technological determinism. Howard (2011, p. 12) affirms this fact when he says that the said technology does not necessarily cause political change, but it does "provide new capacities and impose new constraints on political actors." In the same way the technology of social media cannot bring about change on its own. Rather, the way in which social media is used may precipitate change. In this context, the way in which labour unions in Nigeria during the subsidy removal protests is the crux of the matter. With the significant role which social media have played in revolts and protests elsewhere on the African continent, it is pertinent to examine the relevance of social media in the fuel subsidy removal protests that were held in January 2012. This study ascertains why social media were used instead of traditional media, the purposes for which social media was used during the protests 
and the kinds of messages/comments posted on social media during the protests.

\subsection{Subsidy}

Subsidy is a form of assistance provided by government in the provision of certain products or services. This is often done to make products and services affordable among citizens. In a way, subsidy is provided to make life easier for citizens. Subsidy is government's way of assisting consumers. The prevailing market price of the product may be too exorbitant for the masses. Thus government steps in to make it affordable. According to Ovaga (2012, p.1) subsidy is a form of assistance provided by government to consumers so that they can easily afford a product which is deemed essential in daily life. With subsidy in place, consumers pay less than the prevailing market price of the commodity. With regards to subsidy on petroleum products in Nigeria, consumers have been paying less for the products. Over the years (starting in 1978), there has been gradual removal of subsidy on petroleum products in Nigeria. Coupled with inflation, this gradual removal of subsidy on petroleum products has led to steady increase in the price of petroleum products in Nigeria. However, it is important to note that the revenue derived from the removal of subsidy has not been used for development purposes in Nigeria. Against this back drop, withdrawal of subsidy from petroleum products portrays the government as heartless and insensitive to the predicament of the populace.

\subsection{Protest Mobilisation}

A protest is an expression discontent over an issue. Protests are overt thus expressed in different ways: demonstrations, occupations, strike actions, hunger strikes, etc. Gelber $(2009$, p.1) defines protest as, "a politically expressible, collective gathering in a public place". Protest occurs due to discontent. When people are unhappy about a particular issue, they rise up to challenge the status quo in various ways. In this case, dissatisfaction was caused by removal of petroleum subsidy and the instant increase in the pump price of petrol from N65 to N140. Protests can be peaceful or violent. With reference to protest mobilization in Argentina, Salmenkari (2009, p.8) writes that "protest mobilization simply contained information about where and when the demonstration was to take place and a short introduction to reasons why members should take part." Mobilisation requires a lot of information, especially when grievances are involved. In the January 2012 fuel subsidy removal protests in Nigeria, there was need to explain the hidden issues behind the removal of fuel subsidy and the effect this will have on the lives of ordinary citizens. Such information was essential in ensuring that people turned out to voice their anger and discontent. A protest cannot hold if people are not mobilised to participate. Thus, the two words go hand in hand. For a protest to succeed, someone needs to take up the task of informing participants, giving them reasons for the protest as well as arrange time and venue. These are essential aspects of mobilisation. Mobilisation is similar to coordination, thus all parties need to be convinced of the need to express their dissatisfaction over the issue.

\subsection{Relevance Social Media in Protest Marches and Revolts}

Evidence concerning the relevance of social media in protest is drawn from experiences in various countries of the world in recent history. These countries include: Egypt, Tunisia and Libya. The experience of revolution in these countries is often referred to as the Arab spring. In these countries, the use of social media contributed to the protests which led to the removal of repressive regimes that held sway for long periods of time. The use of social media among activists in Egypt and Tunisia to mobilise citizens to protest acted as a catalyst to the removal of the governments in these countries in 2011. Social media may not have been a direct cause in the course of events but the way it was used by principal actors in these countries precipitated protests where citizens voiced discontent. This chain of events affirms social movement theory as discontent enabled the formation of protest groups via social media. Social media presented protesters an opportunity that is non-existent in mass media. Social media have inherent qualities which when used effectively can mobilize people to protest. Facebook establishes links between friends while Twitter allows users comment about a subject or an issue. These are essential in mobilizing people for protest. Ghannam (2011) writes that, social networks have changed the concept of freedom of expression and association. Prior to the emergence of social networks, this concept was perceived differently. Social networks have improved the capacity of individuals and groups to communitcate, mobilise and acquire technical knowledge. These potentials translate to profound outcomes such as greater voice, political influence, social participation, popular protest, etc.

Social media enable freedom of expression. When contentious issues arise such as the removal of subsidy, people have varied expectations and hopes. Much of public expression toward the issue of subsidy removal cannot find space on the pages of newspapers, magazines, radio or television, due to the restrictive nature of these media. Social media provide avenues for expression and connection between people who have similar ideals. Shirky (2011, p.22) notes that, the "potential of social media lies mainly in their support of civil society and the public sphere - change measured in years and decades rather than weeks or months." Civil society has an opportunity for expression in the use of social media. Ali (2011, p.187-188) relates this fact to the revolts in Egypt, by stating that the role of social media during the uprising in Egypt was striking. Social media enabled self-empowerment among ordinary people in Egypt. Unlike before, these 
people were able to speak and assemble. Such capability was replicated in Tunisia, Libya and Iran. These practical examples affirm the notion of technological determinism as social media have enabled new capacities and prompt critical thought on the potentials of social media during popular discontent, uprising and protest.

Social media use empowers the masses by giving them the opportunity to speak and be heard. Also, with reference to mobilization for protest, social media can be used to gather an assembly of like minded people who are pursuing a particular cause or ideal. When social media had not come into being, all this was not possible with traditional media. The uprising in Egypt is a pointer to the efficacy of social media in protest mobilization. With reference to Tunisia, Breuer (2012, p.3) writes that social media enabled an estimation of turnout at forthcoming events. Thus activists increasingly used social media to organize demonstrations. Facebook for instance, facilitates event planning where users invite others to sign up for created events.

The revolutions in Egypt and Tunisia are focal points in the use of social media during protests and revolts. In each of these countries, social media were central in the revolutions that led to the overthrow of government. As citizens rose against governments for various reasons, organizers of these protests found social media very useful in achieving their goals. In the first place, social media afforded the citizens the opportunity to express criticism of government and discuss these points of view with other citizens. Gradually dissent grew based on the "infectious" nature of these views. In the later stages, social media proved effective in gathering people for protest. These social media have proven to be very useful in the hand of people who organize protests. Howard $(2011$, p.11) is quick to demarcate the lines of influence which social media may have when he notes that, although social media did not aid the inception of democracies, it can entrench this form of government via its "networked design" that is often a threat to authoritarian regimes. The networked design enables citizens to connect with one another and discuss issues with anonymity which encourages self expression. This ability to extend discourse is often not popular among repressive regimes which prefer that controversy be kept hidden.

Indeed the structure of social media is a threat to authoritarian regimes. With social media, people are able to connect with others and receive information which would never have come their way previously. It is important to add that social media can also serve as means of expression for collective consciousness and national struggles. The Nigerian people were united in their collective consciousness about the issue of subsidy removal. It was all too clear that removal of subsidy would perpetuate hardship among the masses. Thus, they collectively opposed this in protest. When this happens oppressive regimes are threatened and seek ways to contain the situation. Salmon et al., (2010, p.160) captures the scenario stating that social media were so powerful that the Egyptian government felt the need to shut internet service as a way to thwart the plans of protesters. The bid by the Egyptian government to restrict and even shut internet use, reveals the awesome potential of this medium especially its information sharing capacities.

Empowerment came through the use of social media. The protesters were determined because of the many online support groups. Although the government in Egypt blocked internet access, these protesters were determined in their resolve to achieve a pre-determined aim. The Egyptian government realised the potential of social media and sought to restrict access to it in order to curb the activities of protesters. However, this effort proved futile in the end. Protesters were able to harness social media and take advantage of the opportunities which it presented to further their cause. At this juncture, the relationship between social media and mobilisation of people during protest should be clarified. Social media may be useful in mobilising people to protest but on its own, it can achieve nothing. It all depends on who uses it and the reasons for which it is used. Khamis and Vaughn (2011, p.25) explain this fact further when they write that the first uprising in Egypt should not be regarded as a Facebook or Twitter revolution eventhough social media played key roles. These social media were only catalysts and proved effective because people were willing to engage in protest at all cost- finance, personal, physical injuries, loss of life, etc. Social media were only vehicles of empowerment during this time.

Having said a lot about effectiveness of social media as a tool for protest mobilization, it is important to point to the fact that these social media were only acting as effective catalysts. It all depended to a significant degree on the way these media were used. Social media may be present in other protest situations, but if they are not used, then they will not produce phenomenal results as it happened in Egypt. It takes the ability of protesters to use social media in order to achieve certain goals. Papic and Noonan (2011, p.1) reiterate this fact stating that social media alone cannot start revolutions in the same way that the recordings of Ayatollah Ruholla Khomeini were not responsible for the 1979 revolution in Iran. The words of Howard (2011, p. 12) sum the essence of this discourse thus, "New information technologies do not topple dictators; they are used to catch dictators off-guard. Today, being an effective social movement means utilizing social media." Social media did not topple the rulers of Egypt, Tunisia or Libya. The citizens who participated in the protests and revolts did it. Social media only helped them along the way. Social media are only tools in the hands of revolutionary groups for the purpose of organization; recruitment; training; lowering costs of participation, etc. The effectiveness of social media depends to a large extent on how these principal actors in 
revolutions use them. Amidst all this explanation, it is still important to note that the revolution would hardly have taken the shape it did in the absence of social media. Although social media was not solely responsible for the revolution, it contributed to a large a large extent in ensuring that it happened. In order to further buttress this fact, Khamis and Vaughn $(2011$, p. 25) quote the words of Iskander (2011) that through its unique network, Facebook amplified, magnified and expedited process of revolution. The AFP (2011) adds that in the absence of Facebook, Twitter, Google, You Tube, the revolts in Egypt would never have happened because social media sparked off the chain of events. Social media and revolts are a give and take scenario. They are not mutually exclusive. Social media inadvertently helped the revolts to "snow ball" across society, turning small protests to huge movements, in line with the social movement theory, which eventually led to the demise of the Egyptian regime. This success is accredited largely to the determination of the masses in Egypt to organize, mobilise and act.

\subsection{Related Empirical Studies}

\subsubsection{Subsidy in the Downstream Oil Sector and the Fate of the Masses in Nigeria}

There is often the need to explain the issues underlying fuel subsidy removal. The reasons for subsidy removal and the attendant increase in the pump price of petrol is not a mystery but a question of interests. In the study, "Subsidy in the downstream oil sector and the fate of the Masses in Nigeria," Ovaga (2012) seeks to find out if the removal of petroleum subsidy is in the interest of the Nigerian masses. Drawing from the findings of other scholars, the study finds that the cost of importing fuel into Nigeria is what the government regards as fuel subsidy. Removal of this subsidy makes petrol unaffordable to Nigerians; since the cost of petrol is increased by importing the product, building new refineries and renovating the existing refineries is key to eliminating such costs and making the product affordable; refining petrol in Nigeria will eliminate the foreign exchange and huge cost incurred by importing petrol; the policy on subsidy in Nigeria has no clear cut boundary for implementation and ; on the whole, fuel subsidy should not be removed because it adversely affects the livelihoods of Nigerians. By way of recommendation, Ovaga (2012, pp. 30, 31) writes that Nigerian National Petroleum Company (NNPC) should be investigated because it is suspect in the misappropriation of funds derived from removal of subsidy. Furthermore, Ovaga (2012) also recommends that subsidy should not be removed in the interest of the masses because proceeds are only embezzled by corrupt officials.

It is inevitable to discuss the issue of subsidy removal without mentioning corruption as long as Nigeria is concerned. Against this backdrop, corruption and misplaced priorities of the Nigerian government is one of the reasons that motivated the protest against subsidy removal. Afterall, there is no valid reason for removing subsidy on petrol thus making the product expensive. In the long run, ordinary Nigerians suffer the brunt of such policies which originate due to the selfish intentions of few. This study supports the social movement theory by highlighting rationale for grievances among Nigerians on removal of subsidy. These grievances are fertile ground for the off shoot of social movements which challenge the status quo due to ill treatment in the polity. Removal of subsidy gives Nigerians a reason to organise thenselves in groups and oppose this unpopular policy.

\subsubsection{Empowering Protest through Social Media}

Social media present a number of opportunities to organizers of protest marches. In the study, "Empowering protest through social media" O'Rourke (2011) discusses the inherent challenges created by social media due to its adoption by direct action protest groups. These protest groups often focus on civil disobedience in pursuit of their objectives. Using a review of related literature and findings from related empirical studies, the study finds that protesters are early adopters of technology who have embraced the use of social media such as Facebook, Twitter, etc. Social media are used by these protesters to broadcast their messages, thus a viable platform that will influence change. Protesters use social media such as Twitter to outmanoeuvre the police. They identify places where police formations are weakest and send messages to members to assemble at such places. Twitter is valuable in organising protesters to come out on the street because, as Risley (2010) notes, it provides the ability to instantly draw upon the collective power of others via cyber space. With social media, protests that took two months to organise, now take two days to organise. This state of affairs creates significant challenges for the police force as they struggle to contain the situation. Apart from this, protesters can render the server of the police force unusable by conducting a Distributed Denial of Service Attack (DDoS). This makes police unable to crack down effectively on the protesters. On the whole, O'Rourke (2011, p.52) concludes that, social media have become significant platforms used to challenge the status quo in many parts of the world. Many protest groups have adopted social media use because of this unique capability. With social media, protesters: organize events in little time and broadcast messages to relevant sections of the community in a way they could not before. In this way they dribble agencies that seek to curb their activities.

Protest groups across the world have recognised the usefulness of social media in organising demonstration and other disruptive events that are aimed at voicing displeasure over a number of issues. They often use media to plan their tactics and as a platform to challenge the status quo- government, police and other security agents. With social media, 
these protest groups are able to reach members easily and organise events in very little time. The limited time in which protests are organised raises significant challenges for the police who have to deal with the situation. These findings affirm the central tenets of technological determinism. Social media have enabled new capacities among citizens and protest leaders thus changed the way revolts are organised. Organisation of these revolts is more efficient and devoid of detection by the police. These can enable protesters carry out their agenda without hinderance from law enforcement.

\subsubsection{The Reasons Social Media Contributed to the 2011 Egyptian Revolution}

The revolution in Egypt is an important landmark in the use of social media in revolts. In the study, "The reasons social media contributed to the 2011 Egyptian revolution," Chebib and Sohail (2011) explore the impact of social media on the 2011 Egyptian revolution (January $25^{\text {th }} 2011$ to February $11^{\text {th }}$ 2011). Using empirical data gathered from other studies, Chebib and Sohail (2011) identify the acceleration effect which is a situation whereby social media enables speedy organization of events. The "acceleration effect" that is identified by Chebib and Sohail (2011) is two pronged. In the first place it provides evidence about the speed with which movements are organized at this point in time, thus reinforcing the social movement theory. Secondly, it extends and introduces a new concept which is related to technological determinism by pointing out the "acceleration effect" which social media have over the organization of events. In the absence of social media, events take a longer time to organize. Social media were also relevant in the Egyptian revolution because they were a rich source of information for international news organizations and news agencies. Furthermore, Chebib and Sohail (2011) find that social media were useful in the Egyptian revolution because they were accessible to the Egyptian populace, enabled instant updated information and were easy to use. Accessibility is defined in terms of: low barriers to entry and low communication barriers. Opening of accounts on social media are free thus limiting barriers to entry. Furthermore, social media is not as restrictive as traditional media, thus people interact freely on social media. Social media is also readily available as internet services are available on mobile devices such as mobile phones, ipads, etc. Chebib and Sohail $(2011$, pp. 155, 156) note that social media cannot trigger revoliutions. In the 2011 Egyptian Revolution, social media acted as facilitators and accelerating agents by helping the youth to hold online discussions; meetings; organize protests; provide updates, etc. Due to the capacity of social media, the Egyptian government blocked social media and later internet access. However, this was overcome by workarounds. Social media merely acted as a catalyst in facilitating the Egyptian Revolution. The stakeholders found social media useful in many ways as they revolted against the status quo. In the end, they were victorious as they pulled down the thirty (30) year old regime.

\subsubsection{Social Media and Protest Mobilisation: Evidence from the Tunisian Revolution}

Social media play an important role in protest mobilisation. In the study, "Social media and protest mobilisation: Evidence from the Tunisian revolution" Breuer, Landman and Farquhar (2012) analyse the use of the internet (as a significant resource) for protest mobilisation in Tunisia. The study gathered evidence (between February and May 2012) from 16 elite interviews with digital activists and a survey of 437 respondents who are Tunisian internet users. The notion of "digital activists" suggests elements of technology determinism. The survey was hosted online thus they respondents were a convenience sample. Only those who had internet access and chose to participate in the survey were respondents. Findings of the study show that: $73.8 \%$ of respondents learned via the internet that a significant number of people had signed up for a demonstration in their town, village, city, settlement or area; $73 \%$ of respondents agreed/strongly agreed that in order to keep abreast of what was happening regarding protests they are willing to connect with people on social networks whom they had not known before; and the respondents had varying degrees of membership of different social network sites- Facebook (98.4\%), YouTube (46.4\%), Twitter (42.7\%), LinkedIn (23.0\%), Dailymotion (13.7\%), Flickr (7.4\%), and Vimeo (7.1\%). The study finds that there is a relationship between level of internet use and level of protest activity. The paper concludes that internet/social media use contributed in mobilising citizens to protest against the government in Tunisia. In line with the social movement theory, it was possible to mobilise the citizens against the government because the citizens are increasingly frustrated due to the absence of socio-economic opportunities and restrictions placed by the government on internet use for political activity. On the whole, Breuer, Landman and Farquhar (2012, p. 30) conclude that, the internet and social media transcended geographical and socio-economic imbalances to enable a national collective identity unified in protest against the upopular regime. The internet was the basis upon which popular greviances were articulated. Also, it was a resource for collective action that led to successful protest which toppled the regime.

The citizens of Tunisia were united on the internet despite their differences, because they share a common struggle. The hardships of the time enabled them look beyond social disparities and form a force strong enough to remove the unpopular government. The internet via social media sites was the "vehicle" that made this possible, thus reinforcing the tenets of technological determinism. The various uses to which the internet was put made the citizens mobilise themselves towards achieving a common goal. 


\section{Rationale for the Protests against Oil Subsidy Removal}

The fuel subsidy removal protests were motivated by antecedents of history. Elsewhere, the removal of fuel subsidy is supposed to be beneficial to citizens. However, in Nigeria, this has not been the case. Over the years, fuel subsidy has been removed gradually by successive governments, yet there has been nothing tangible to show for it with regard to the living standards of ordinary Nigerians. Ering and Akpan (2012, p.2) sum the reason behind the January 2012 fuel subsidy removal protests as dissatisfaction with previous removal of subsidy on petroleum products in Nigeria. In the past, subsidy has been removed but it has not translated to improved living conditions for Nigerians. Nigerians still suffer from under development in many spheres. Successive rulers in Nigeria and their associates are the only ones who benefit from the removal of subsidy on petroleum products.

In 1978, the military regime of Olusegun Obasanjo increased the pump price of petrol from 8.4 kobo to 15.37 kobo per litre. This was done in order to raise money to run the administration as well as fund the 1979 democratic elections. In addition, money generated from the increase was expected to cater for the social needs of Nigerians. Similarly, on March $31^{\text {st }} 1986$, the military regime of Ibrahim Babangida increased the price of petrol to 39.5 kobo per litre and did not stop there. On $10^{\text {th }}$ April 1988, the same regime increased the price of petrol yet again to 42 kobo per litre. On January $1^{\text {st }} 1989$ the price was increased to 60 kobo per litre. Yet again, on $6^{\text {th }}$ March 1991, the price of petrol was increased to from 60 kobo per litre to 70 kobo per litre. On $8^{\text {th }}$ November 1993, the price was increased to N5 (five naira) per litre. This increase caused a wave of mass protests across Nigeria and the price was reduced to N3.25 (three naira, twenty five kobo) per litre on 22 November 1993. The increase of the pump price of petrol did not stop there. On $2^{\text {nd }}$ October 1994 it was increased to N15 (fifteen naira) but was reduced after two days to N11 (eleven naira) due to mass protests. On $20^{\text {th }}$ December 1998, the price of petrol was increased again to N25 (twenty five naira) per litre but was reduced to N20 (twenty naira) per litre on $6^{\text {th }}$ January 1999 after sustained protests from Nigerians and organised groups.

With the return to democracy in 1999 and the subsequent eight (8) year term of Olusegun Obassanjo, the pump price of petrol was increased four (4) times namely: $1^{\text {st }}$ June 2000, $1^{\text {st }}$ January $2002,23^{\text {rd }}$ June 2003, and June 2007. On $1^{\text {st }}$ June 2000 the pump price of petrol was increased to N30 (thirty naira) per litre but one week later, was reduced to N25 (twenty five naira) per litre after protests from organised labour, civil society and the Nigerian populace. On $13^{\text {th }}$ June 2000 , the price was further reduced to N22 (twenty two naira) per litre. On $1^{\text {st }}$ January 2002 , the pump price of petrol was increased to N26 (twenty six naira) per litre and on $23^{\text {rd }}$ June 2003 it was further increased to N40 (forty naira) per litre. In June 2007, the pump price was further increased to N70 (seventy naira) per litre but was reduced to N65 (sixty five naira) per litre by the Yar'Adua administration. Social Action (2012, p.14) sums the history of fuel subsidy removal in the table below.

\begin{tabular}{lll}
\hline s/n & Dates & Increment \\
\hline 1 & $1^{\text {st }}$ October 1978 & 8.45 kobo to 15.3 per litre \\
2 & $20^{\text {th }}$ April, 1982 & 20 kobo per litre \\
3 & $31^{\text {st }}$ March, 1986 & 39.5 kobo per litre \\
4 & $10^{\text {th }}$ April 1988 & 42 kobo per litre \\
5 & $1^{\text {st }}$ January, 1989 & 60 kobo per litre (private) \\
& & 42 kobo (commercial) \\
6 & $19^{\text {th }}$ December, 1989 & 60 kobo per litre \\
& & (uniform pricing) \\
7 & $6^{\text {th }}$ March 1991 & 70 kobo \\
8 & $8^{\text {th }}$ November 1993 & N5 per litre \\
9 & $22^{\text {nd }}$ November 1993 & Reduced to N3.25k after massive protests. \\
10 & $2^{\text {nd }}$ October, 1994 & N15 per litre \\
& & Reduced to N11 two days \\
& & later \\
11 & $20^{\text {th }}$ December, 1998 & N25 per litre \\
& & Reduced to N20 a month \\
& & later on 6 Jan 1999 \\
12 & $1^{\text {st }}$ June, 2000 & N30 per litre. Reduced to N25 one week later. \\
& & Further reduced to N22 five days later on 13th June, 2000 \\
13 & $1^{\text {st }}$ January, 2002 & N26 per litre \\
14 & $23^{\text {rd }}$ June, 2003 & N40 per litre \\
15 & June 2007 & N70 per litre reduced to N65 by Yar'Adua administration \\
16 & January 2012 & N140 per litre reduced to N97 after mass protests \\
\hline
\end{tabular}


From the historical account stated above, massive protests have often accompanied the removal of fuel subsidy. These protests are held by organised labour groups, civil society organisations and members of the Nigerian public. Often, these protests have had the effect of reducing the price of petrol but after a little while it is increased again. In recent history, only two (2) governments spared the Nigerian populace the agony of increasing the pump price of petrol. These administrations were those of Buhari and Yar'Adua. The various governemtns that removed subsidy and increased the pump price of petrol have been quick to defend their actions. Onanuga (2011, p. 3) quotes Lamido thus, "If we borrow to subsidize today, it is our children that are subsidizing us let us take a difficult decision today and make tomorrow better by supporting the removal of subsidy." However, Sobowale $(2012$, p.42) is quick to counter the defense mechanism employed by government when he quotes the words of I. F. Stone as follows: "Every government is run by liars and nothing they say should be believed." This conclusion finds credence in the fact that much of Nigeria remains under developed despite the many times in which subsidy on petroleum products has been removed.

\section{Methodology}

The study used survey research design. The population of study were members of the Nigerian Labour Congress (NLC), trade unions and civil society organisations in Abuja, Nigeria, who used social media during the January 2012 protests against the removal of fuel subsidy. It was important for the study to use only members of these groups who used social media during the protests because they are the only ones that can provide valid data that is needed to answer the research questions. Abuja was selected because it is the capital city of Nigeria and a significantly large number of protests were held there. Due to the nature of the subject at hand, respondents were promised anonymity. During the sampling procedure, the study ended up with one hundred and twenty eight (128) respondents. From the total number of respondents, twenty (20) were members of the NLC, forty three (43) were members of trade unions and sixty five (65) were members of civil society organisations.

\section{Data Presentation}

Table 1. Purpose for social media use.

\begin{tabular}{|c|c|c|c|}
\hline $\mathbf{s} / \mathbf{n}$ & Purpose & Frequency & Percentage \\
\hline 1 & $\begin{array}{l}\text { Informing people about the protests especially when and where the protests would } \\
\text { hold }\end{array}$ & 15 & 11.7 \\
\hline 2 & Explaining reasons for the protest by providing cogent examples & 16 & 12.5 \\
\hline 3 & Updating people of negotiations between labour and government & 13 & 10.2 \\
\hline 4 & Statistical evidence of mismanagement in government providing relevant data & 47 & 36.7 \\
\hline 5 & Posting pictures of protests held in other parts of the country & 12 & 9.4 \\
\hline 6 & $\begin{array}{l}\text { Spreading humour about the protests by pointing out funny incidents related to the } \\
\text { protest }\end{array}$ & 05 & 3.9 \\
\hline 7 & Running down government officials by citing instances of misconduct & 06 & 4.7 \\
\hline 8 & $\begin{array}{l}\text { Links with newspapers/magazines that reported events and issues relevant to the } \\
\text { protest }\end{array}$ & 04 & 3.1 \\
\hline \multirow[t]{2}{*}{9} & Verification of information so that the populace is not mislead by rumour & 10 & 7.8 \\
\hline & Total & 128 & 100 \\
\hline
\end{tabular}

Table 1 presents a distribution of respondents according to the most frequent purpose to which social media was used during the January 2012 fuel subsidy removal protests in Nigeria. From the table, 15 respondents (representing 11.7 percent of the total population) indicated that social media was used to inform people about the protests; 16 respondents (representing 12.5 percent of the total population) indicated that social media was used to explain the reasons for the protest; 13 respondents (representing 10.2 percent of the total population) indicated that social media was used to update people of the negotiations with government; 47 respondents (representing 36.7 percent of the total population) indicated that social media was used to circulate statistical evidence of mismanagement in government; 12 respondents (representing 9.4 percent of the total population) indicated that social media was used to post pictures of the protest; 5 respondents (representing 3.9 percent of the total population) indicated that social media was used to spread humour about the protest; 6 respondents (representing 4.7 percent of the total population) indicated that social media was used to run down government officials; 4 respondents (representing 3.1 percent of the total population) indicated that social media was used to provide materials and links to newspapers and magazines while; 10 respondents (representing 7.8 percent of the total population) indicated that social media was used to verify information.

Most respondents (representing 36.7 percent of the total population) indicated that social media was used to circulate statistical evidence of mismanagement in government while few respondents (representing 3.1 percent of the total population) indicated that social media was used to provide materials and links to newspapers and magazines. Labour 
leaders gathered statistical evidence of mismanagement by government officials backing these up with data in order to convince the populace. In some instances, such statistical evidence was compared with data from other progressive countries in order to prove the point that Nigeria is backward and has a lot of catching up to do. Evidence such as these provided a reason for people to get up and join the protest. Statistical evidence often breeds conviction. People are often convinced by various factors such as religion, ethnicity, political ideology, etc. However, statistical evidence is devoid of bias and forms a valid basis for conviction. Statistical evidence on social media about the mismanagement by the Nigerian government would have given people a reason to participate in the protest against the removal of fuel subsidy.

Table 2. Reasons for social media use

\begin{tabular}{clcc}
\hline s/n & \multicolumn{1}{c}{ Reasons } & Frequency & Percentage \\
\hline 1 & Immediacy & 25 & 19.5 \\
2 & Ease in publication & 13 & 10.2 \\
3 & Unrestricted & 62 & 48.4 \\
4 & Reach & 10 & 7.8 \\
5 & Multimedia & 11 & 8.6 \\
6 & Low cost & 07 & 5.5 \\
\hline \multicolumn{2}{r}{ Total } & $\mathbf{1 2 8}$ & $\mathbf{1 0 0}$ \\
\hline
\end{tabular}

Table 2 presents a distribution of respondents according to the most frequent reason for social media use instead of traditional media. From the table, 25 respondents (representing 19.5 percent of the total population) indicated immediacy; 13 respondents (representing 10.2 percent of the total population) indicated ease in publication; 62 respondents (representing 48.4 percent of the total population) indicated the unrestricted nature of social media; 10 respondents (representing 7.8 percent of the total population) indicated reach of social media; 11 respondents (representing 8.6 percent of the total population) indicate the multimedia nature of social media while; 7 respondents (representing 5.5 percent of the total population) indicate the low costs associated with social media.

Most respondents (representing 48.4 percent of the total population) indicated the unrestricted nature of social media while few respondents (representing 5.5 percent of the total population) indicate the low costs associated with social media.

The unrestrictive nature of social media makes it popular and is a "breath of fresh air" in comparison to traditional media. Related to the unrestrictive nature of social media is the fact that users have the option of anonymity. In other words, they can choose to remain unknown. This affords the opportunity for users to express themselves without fear of persecution. Given this scenario, protesters are very critical of government and contribute in depth to debates on contentious issues.

Table 3. Messages/comments posted on social media

\begin{tabular}{|c|c|c|c|}
\hline $\mathbf{s} / \mathbf{n}$ & Messages/Comments & Frequency & Percentage \\
\hline 1 & Expressing ill wishes towards government and predicting doom & 05 & 3.9 \\
\hline 2 & Citing instances of misappropriation and corruption by government officials & 41 & 32 \\
\hline 3 & $\begin{array}{l}\text { Highlighting the insensitivity of government to the populace by recounting campaign } \\
\text { promises and comparing these with unpopular policies }\end{array}$ & 20 & 15.6 \\
\hline 4 & Hardship among populace due to subsidy removal & 21 & 16.4 \\
\hline 5 & Increased prices of goods and services & 15 & 11.7 \\
\hline 6 & Regrets for voting current government & 12 & 9.4 \\
\hline 7 & Historical analysis & 10 & 7.8 \\
\hline \multirow[t]{2}{*}{8} & Reiterating loyalty to the protest & 04 & 3.1 \\
\hline & Total & 128 & 100 \\
\hline
\end{tabular}

Table 3 presents a distribution of respondents according the frequency of comments which they posted on social media during the fuel subsidy removal protests. From the table, 5 respondents (representing 3.9 percent of the total population) indicated that the comments were about ill wishes towards government; 41 respondents (representing 32 percent of the total population) indicated that the comments were about corruption in government; 20 respondents (representing 15.6 percent of the total population) indicated that the comments were about the insensitivity of government; 21 respondents (representing 16.4 percent of the total population) indicated that the comments were about hardship due to subsidy 
removal; 15 respondents (representing 11.7 percent of the total population) indicated that the comments were about increased prices of goods and services; 12 respondents (representing 9.4 percent of the total population) indicated that the comments were about regrets for voting the current government; 10 respondents (representing 7.8 percent of the total population) indicated that the comments were about historical analysis of subsidy removal while; 4 respondents (representing 3.1 percent of the total population) indicated that the comments were about reiterating loyalty to the cause of the protests.

Most respondents (representing 32 percent of the total population) indicated that the comments were about corruption in government while, few respondents (representing 3.1 percent of the total population) indicated that the comments were about reiterating loyalty to the cause of the protests.

The corrupt nature of the Nigerian government dominated discussion. This direction of discourse explained the futility of fuel subsidy removal. In the end, the gains which are supposed to be made by removing fuel subsidy will be lost to corruption. These comments point to the fact that removal of subsidy should not be the issue, rather efforts should be geared towards tackling corruption.

\section{Findings}

The unrestrictive nature of social media is the most significant reason for its use during the fuel subsidy removal protests. Traditional media on the other hand is very restrictive as it has a lot of gatekeepers and factors which bar access. Other reasons for the use of social media during the January 2012 fuel subsidy removal protest include: immediacy of social media; ease in publication devoid of gatekeepers; reach in terms of audience; multimedia nature of social media and low cost of access to social media.

Social media were used most frequently to circulate statistical evidence of mismanagement in government during the January 2012 fuel subsidy removal protests. Other purposes to which social media were used include: informing people about the protests; explaining reasons for the protest; updating people of negotiations with government; posting pictures of protests; spreading humour about the protests; running down government officials; links with newspapers/magazines and; verification of information.

Most of the comments on social media during the January 2012 fuel subsidy removal protest were about corruption in government. Other comments were on the following issues: ill wishes towards government; corruption in government; insensitivity of government; hardship due to subsidy removal; increased prices of goods and services; regrets for voting current government; historical analysis and; reiterating loyalty to the ideals of the strike.

The findings of this study re-iterate the assumptions of the social movement theory which identifies forcible repression as a precursor of protest. Social media are unrestrictive and give citizens the opportunity to express themselves when episodes of "forcible repression" such as removal of fuel subsidy occur. Traditional media do not give citizens the opportunity to be critical of government. This is often counterproductive and breeds tyrannical regimes. Technology is ever changing and as it does, it imposes new constraints of political actors. In this way, technological determinism is brought to bear on the findings of this study. Social media was used to distribute statistical data on the many examples where the Nigerian government is inefficient. This gave protesters a reason to turn out on the street as well as imposed new constraints on political actors, as they had to find ways of tackling the situation.

\section{Conclusion and Recommendation}

Traditional media are riddled with restrictions which often bar access. Some of the factors which make traditional media restrictive include: gatekeepers, professional training, cost, ownership, etc. However, social media are free of such restrictions. This makes it easier for users to transmit information on social media. For this reason, social media was used very often by labour unions in Abuja during the fuel subsidy removal protest in Nigeria. The uses of social media were an opportunity for aggrieved parties to express themselves about the contentious issues that were raised by the removal of fuel subsidy. Relevant organs of government can measure public opinion by taking into consideration the various messages posted on social media. This will helpfully influence government policy in the right direction. Most of the comments posted on social media were about corruption and mismanagement in government. Also, social media was used to provide statistical evidence about government, corruption and mismanagement. These are pointers to the fact that something needs to be done urgently for government to redeem its credibility in the mind of the Nigerian masses.

\section{References}

Ali, A. H. (2011). The Power of Social Media in Developing Nations: New Tools for Closing the Global Digital Divide and Beyond. Harvard Human Rights Journal 24.

Bennett, W. L. (2003). New Media Power: The Internet and Global Activism, in N. Couldry and J. Curran (eds.) 
Contesting Media Power, New York: Rowman and Littlefield.

Boyd, D. M. \& Ellison, N. B. (2007). Social network sites: definition, history and scholarship. Journal of Computer Mediated Communication, 13(1). http://dx.doi.org/10.1111/j.1083-6101.2007.00393.x

Breuer, A. (2012). The role of social media in mobilizing political protest: Evidence from the Tunisia revolution. Discussion Paper Bonn: German Development Institute.

Breuer, A., Landman, T., \& Farquhar, D. (2012). Social media and protest mobilisation: Evidence from the Tunisian revolution. An unpublished paper prepared for the $4^{\text {th }}$ European Communication Conference for the European Communication Research and Education Association (ECREA) Instanbul, Turkey.

Castells, M. (1996). The Rise of the Network Society Oxford: Blackwell.

Chatora, A. (2012). Encouraging political participation in Africa. Situation Report Pretoria, South Africa: Institute for Security Studies.

Chebib, N. K. \& Sohail, R. M. (2011). The Reasons Social Media Contributed To The 2011 Egyptian Revolution. International Journal of Business Research and Management (IJBRM), 2(3).

Deloitte (2012). Social Media in Africa Johannesburg: Deloitte Touche Tohmatsu Limited.

Downing, J. H. (2001). Radical Media: Rebellious Communication and Social Movements. London: Sage.

Ering, S. O. \& Akpan, F. U. (2012). The Politics of Fuel Subsidy, Populist Resistance and its Socio-Economic Implications for Nigeria. Global Journal of Human Social Science, 12(7).

Farber, H. S. (2001). Notes on the Economics of Labor Unions. Princeton University Working Paper No. 452.

Fuchs, C. (2010). Alternative media as critical media. European Journal of Social Theory, 13(2). http://dx.doi.org/10.1177/1368431010362294

Gelber, K. (2009). The right to protest and Australian political culture. Paper presented at the Australian Political Studies Association, Sydney. http://ssis.arts.unsw.edu.au/staff/katharine-gelber-1109.htm Accessed December $3^{\text {rd }}, 2012$

Gerlach, L. P. (2001). The Structure of Social Movements: Environmental Activism and Its Opponents, in J. Arquilla and D. Ronfeldt (eds.) Networks and Netwars: The Future of Terror, Crime, and Militancy Santa Monica: Rand, pp. 289-309.

Ghannam, A. (2011). Little sympathy in Cairo for Mubarak family. http://www.bbc.co.uk/news/world-middle-east-13072631 Accessed November 18th 2012.

Ghannam, J. (2011). Social media in the Arab world: Leading up to the uprisings of 2011. A Report to the Center for International Media Assistance. http://cima.ned.org/publications/social-media-arab-world-leading-uprisings-2011-0 Accessed November 18th 2012.

Heberle, R. (1995). Social Movements and Social Order, in Lyman, S.M. (eds.) Social Movements: Critiques, Concepts, Case-Studies, London: Macmillan Press Ltd.

Howard, P. N. (2011). The Digital Origins of Dictatorship and Democracy: Information Technology and Political Islam. Oxford: Oxford University Press.

International Telecommunications Union. (2013). Study on International Internet Connectivity in sub-Saharan Africa Geneva, Switzerland: Intenrational Communications Union.

Iskander, A. (2011). Adjunct faculty at Georgetown University's Center for Contemporary Arabic Studies. Phone interview on April 24, , In Khamis, S. \& Vaughn, K. "Cyberactivism in the Egyptian Revolution; How Civic Engagement and Citizen Journalism Tilted the Balance" Arab Media and Society 14.

Khamis, S. \& Vaughn, K. (2011). Cyberactivism in the Egyptian Revolution: How Civic Engagement and Citizen Journalism Tilted the Balance. Arab Media and Society, 14.

Mayer, M. (1995). Social-Movement Research in the United States: A European Perspective, in Lyman, S.M. (eds.) Social Movements: Critiques, Concepts, Case-Studies, London: Macmillan.

McCarthy, J. D. \& Zald, M. N. (1987). Resource Mobilization and Social Movements: A Partial Theory. In Zald M.N and J.D. McCarthy (eds) Social Movements in an organizational society: Collected Essays. Oxford: Transaction Books.

Onanuga, A., (2011). Subsidy Battle in Lagos: labour, government forces clash at Town Hall Meting, The Nation, Friday, December 23, pp 1-3. 
O'Rourke, S. (2011). Empowering protest through social media. Proceedings of the 2nd International Cyber Resilience conference, Edith Cowan University, Perth Western Australia $1^{\text {st }}-2^{\text {nd }}$ August.

Ovaga, O. H. (2012). Subsidy in the downstream oil sector and the fate of the Masses in Nigeria. Kuwait Chapter of Arabian Journal of Business and Management Review 1 (6)

Papic, M., \& Noonan, S. (2011). Social Media as a Tool for Protest. Security Weekly February $3^{\text {rd }}$

Rauch, J. (2007). Activists as Interpretive Communities: Rituals of Consumption and Interaction in an Alternative Media Audience, Media, Culture \& Society, 29(6), 994-1013.

Risley, D. (2010). The Twitter Manual. http://www.davidrisley.com/reports/twittermanual.pdf Accessed December 3rd, 2012.

Salmenkari, T. (2009). Political Opportunities and Protest Mobilization in Argentina. El Norte Finnish Journal of Latin American Studies 4.

Salmon, C. T., Fernandez, L. \& Post, L.A. (2010). Mobilizing public will across borders: Roles and Functions of communication processes and technologies. Journal of Borderlands Studies, 25(3\&4), 159-170. http://dx.doi.org/10.1080/08865655.2010.9695778

Shirky, C. (2011). The political power of social media: Technology, the public sphere, and political change. Foreign $\begin{array}{lllll}\text { Affairs. } & \text { Retrieved } & \text { April } & \text { 15, 2011, from }\end{array}$ http://www.foreignaffairs.com/articles/67038/clay-shirky/the-political-power-of-social-media Accessed November 18th, 2012.

Social Action. (2010). Fuels of dissent: Politics, corruption and protest over fuel subsidy in Nigeria. Social Action Briefing Port Harcourt, Nigeria: Social Development Integrated Centre.

The Independent. (2011). Social media, cellphone video fuel Arab protests. The Independent. Retrieved from http://www.independent.co.uk/life-style/gadgets-and-tech/social-mediacellphone-video-fuel-arab-protests-2227088 .html Accessed November 18th 2012.

\section{$(\mathrm{cc})$ EY}

This work is licensed under a Creative Commons Attribution 3.0 License. 